\title{
Research on Legal Issues of Chinese Equity Holding
}

\author{
Hanyu Tang ${ }^{1, *}$ Debin Hou ${ }^{1}$ \\ ${ }^{1}$ School of Law, Changchun University of Science and Technology, Changchun, Jilin 130012, China \\ "Corresponding author. Email: $1301108962 @ q q . c o m$
}

\begin{abstract}
Equity holds its upward and positive side on behalf of investors, which hides it behind the scenes, expands its funding channels for the company, and rejuvenates the market. However, Chinese equity holdings also have their downsides and negative aspects, such as vague legal nature, incomplete legal provisions, and incomplete protection of the rights and interests of entities. This article compares the common law system and the civil law system of the equity holding system, taking its lean points, such as clarifying the legal nature, improving the legal regulations, and balancing the rights and interests of the main body, and further presenting the legal issues of the equity holdings in China in a systematic way.
\end{abstract}

Keywords: Nominee shareholder, Actual investor, Legal perfection.

\section{INTRODUCTION}

As a common investment method, equity holdings have realized the gathering of idle funds in society and the maximization of resource allocation, which has played a pivotal role in the development of Chinese economy. However, there are bound to be fetters behind the positive impact. Due to the lack of legal regulations for equity holdings in China, relevant issues have not been systematically regulated. Therefore, in practice, complicated judicial disputes caused by equity holdings have not been properly handled. This article puts forward the related disputes of equity holdings and consults relevant theoretical frameworks and analyses, hoping to provide ideas for the application of the legal system of equity holdings in China.

\section{THE CONCEPT AND SIGNIFICANCE OF EQUITY HOLDING}

\subsection{The Concept of Equity Holding}

As an "imported product", equity holdings frequently appear in the field of Chinese companies. However, this does not mean that the concept of equity holdings has become unified, and a certain definition has not been fully recognized by the theoretical community. Equity holding is considered by some scholars to actually contribute capital to purchase equity in the name of others, but the company's activities are indirectly participated by the actual investor, without the participation of nominal shareholders. Some scholars also believe that the concept of proxy equity refers to a legal phenomenon in which the nominal shareholder is in the clear and the actual investor is secretly separated from each other. Of course, there are also a few scholars who believe that the definition of equity holding on behalf of others refers to a way of disposing of equity by the actual investor based on their own factors and thus agreeing with others. It is not difficult to extract the characteristics of equity holdings from the viewpoints of the above scholars: first, the legal relationship of equity holdings is established by the actual investor and the nominal shareholder; second, the agreement on equity holdings is not the actual investor With the company, but with the nominal shareholder; third, the actual investor is not a company shareholder, but it is an indirect exerciser participating in the company's activities, and at the same time it obtains dividends from the company's profits. The author holds that the holding of shares by proxy refers to the actual investors hiding their identities in the market operation activities by signing agreements with nominal shareholders, it is a legal phenomenon that the nominal shareholders indirectly acquire the stock right of the company in order to manage the company and distribute the profits. 


\subsection{The Meaning of Equity Holding}

One is conducive to concealing the identity of investors. Investors often invest in different projects, so they are often faced with more complex social environments and interpersonal relationships, so they pay more attention to their personal information than ordinary people. It is precisely from this that equity holdings came into being, and its flexibility and concealment characteristics Greatly stimulate the investment enthusiasm of investors. Equity holdings can better avoid the leakage of personal information, and investors hiding behind the scenes are more conducive to their gains.

The second is conducive to broadening the company's funding channels. The development of the company not only relies on operation and income, but more importantly, financing and refinancing. Equity holding is different from traditional shareholders, but a new type of shareholder's shareholding. Its new type is that the investment subject is not only traditional shareholders, but also including the third person.

Third, it is conducive to revitalizing the market economy. The development of market economy is inseparable from the vigorous promotion of market economy entities, but market economy should also take the initiative to produce new chemical changes with market economy entities to promote a bumper harvest of economic value. The company is one of the mainstays of the market economy, and the fundamental reason from weak to strong is the continuous operation of market economic vitality and the continuous accumulation of wealth. Equity holdings use new forms to inject capital into the company, add economic vitality, and import capital to promote the vigorous development of the market economy.

\section{AN INVESTIGATION OF THE LEGAL RULES FOR THE REPRESENTATIVE HOLDING OF FOREIGN EQUITY HOLDING}

\subsection{Interpretation of the System of Equity Substitution in the Common Law System}

Equity holdings first appeared in equity trusts in the common law system. The issue of equity holding is mainly interpreted by the trust system in developed countries such as Europe and the United States. Compared with China, the company legal system is more complete. The essence of a trust is that the trustee manages and disposes of the trustee's property based on the trustee's trust in the trustee. The trustor and the trustee must follow the corresponding obligations. If the real property needs to be transferred, the latter must be faithful to the trustee's property, and have good faith management.

The "American Standard Company Act" stipulates that two shareholders can exist in the same share capital contribution. Chinese law stipulates that the person who registers the stock in the company register is the company's shareholder. The US law and Chinese law are consistent in the determination of shareholders. However, the more complete US law is that the "beneficiary" of the stock is also defined as the company's shareholder. But it must be based on the confirmation of the prominent shareholders. You can turn the dormant shareholders into a prominent shareholder. The United States implements dual-track management of nominal shareholders and equity trusts. In the equity holdings, the nominal shareholders are the trustees and the dormant shareholders (that is, the actual investors in China) are the principals and beneficiaries. At the same time, equity holdings are regulated through the equity trust system. The "American Standard Corporation Act" stipulates that the exercise of shareholder rights is quite different from that of China. The former stipulates that silent shareholders supervise nominal shareholders, and vice versa. The United States grants both parties the right to oversee to balance their interests, reduce the possibility of abuse of shareholder rights, and to some extent maintain the company's long-term and stable development.

Compared with the American law, the British law has more detailed provisions on the agreement between the named shareholder and the actual investor in the equity holding agent, allowing both parties to enjoy shareholder rights, which means that the shareholder rights are divided. The prerequisite for the division is to file with the company. The provisions of the British law on proxy holdings are not only a manifestation of the effectiveness of the publicity of the shareholder register, but also further indicate the freedom of the two parties when signing the agreement. Of course, the registration of the company to the nominal shareholder is to prevent the abuse of shareholder rights. As far as investors are concerned, it's necessary to protect their corresponding rights and interests from infringement.

The Anglo-American law system uses the trust system to regulate the related issues of the equity holdings, and the solution provides new solutions to the development of the equity holdings system in 
China. First of all, the rights and obligations between the principal and the trustee should be clarified to reduce the disputes between the nominal shareholders and the actual investors caused by the invalidation of the holding agreement. Secondly, starting from the nature of the equity holding and the purpose of the interests of the equity holding, it coincides with the concept of the trust legal system. Finally, in the United States and the United Kingdom, the former grants dormant shareholders and nominal shareholders the right to supervise, while the latter determines the scope of shareholder rights through filing with the company, both of which provide new legal applications for the resolution of legal disputes concerning equity holdings in practice.

\subsection{The Interpretation of the System of Equity Holding by the Continental Law System}

The civil law system and the common law system are working in two ways to solve the problem of equity holdings. Compared with the common law system applying the trust legal system, the civil law system prefers to solve related problems through the "Civil Code" and "Company Law". More emphasis is placed on publicity and following appearance doctrine. Taking the German "Company Law" as an example, the shareholders of the company are only registered shareholders and not shareholders of the anonymous contributor, but the company's equity income rights are enjoyed by the shareholders of the implicit contributor. When their rights and interests are damaged, they can pass the industrial and commercial registration, the shareholder register, etc. records the exercise of the right to object. Japan's "Corporate Law" is a follower of strict appearance doctrine on the issue of equity holdings, that is, company shareholders are nominal shareholders recorded on the shareholder register and enjoy shareholder rights. It is considered that the nominal shareholder and the silent investor are the agency legal relationship, and the shareholder identity of the nominal shareholder is used by the silent investor to obtain the company's shareholder rights. South Korea's "Korea Commercial Code" classifies hidden investors based on whether the named shareholders are aware of it or not, which is different from other civil law countries. If the actual shareholder is a "false investor" or "borrowed investor", then the false investor and the false investor shall enjoy the company's rights and interests and bear shareholder responsibilities. At the same time, under the subscription system, South Korea adopts the method of jointly and severally liable for the issue of capital contribution defects by the hidden investor and the named shareholder.

It is not difficult to see from Germany, South Korea, and Japan's solution to the issue of equity holdings that they are practitioners of strict publicity and registration of appearance doctrine, and recognize that shareholders registered in legal documents enjoy shareholder rights and assume shareholder responsibilities. Civil law countries are more inclined to protect the interests of bona fide third parties. The hidden investor in Germany has the right to object, the distinction between legal and illegal equity holdings in South Korea, and the liability for defects in capital contributions shall be jointly and severally liable by the hidden investor and the named shareholder, which lay the foundation for the legislative reform of equity holdings in China.

\section{EXISTING LEGAL DILEMMAS IN CHINESE EQUITY HOLDING}

\subsection{The Legal Nature of Equity Holding Is Vague}

The clarity of the nature of the law is a sufficient condition for the correct application of the law. At present, there are still many disputes on the vague legal nature of equity holdings: agency relationship theory, that the nominal shareholder in equity holding is essentially the agent of the actual investor; equity transfer theory, holding that equity holding is a twotiered equity transfer Relationship, that is, one is the initial transfer of the actual investor to the nominal shareholder, and the other is the return transfer from the nominal shareholder to the actual investor, which is the process of transfer of equity; the contractual relationship says that the equity holding is based on the nominal shareholder and the actual shareholder. Shareholders reach an agreement to clearly stipulate the rights and obligations exercised by both parties; the trust relationship theory believes that equity holding is that the actual investor entrusts his own equity to the nominal shareholder to manage the equity. In judicial practice, there are endless cases of proxy holding. If the legal nature of proxy holding is not clear, it is likely to cause differences in the application of the law and affect the outcome of the judgment.

\subsection{Legal Provisions for Equity Holdings Are Incomplete}

The legal provisions of Chinese equity holdings are not only embodied in the "Civil Code", 
"Company Law" and "Company Law Judicial Interpretation III", but the relevant legal provisions are still not perfect. Article 24 of the "Company Law Judicial Interpretation III" stipulates the validity of the equity holding agreement, the ownership of investment rights, and the acquisition of shareholder status by the actual investor; Article 25 stipulates that a third party acquires equity in good faith and a nominal shareholder the compensation liability for the liability of the shareholder for the defects of the capital contribution and the recovery from the actual investor. Of course, Chinese legal provisions on proxy equity holdings are not limited to the abovementioned display, but are also reflected in Articles 14 to 19 of the "Provisions on Disputes in Foreign Investment Enterprises (1)". The above-mentioned laws basically cover the acquisition of equity between the nominal shareholder and the actual investor in equity holdings, the disposal of equity, and the liability of the nominal shareholder and the actual investor due to equity disputes, but this does not apply to the numerous cases in practice. I did not submit satisfactory answers to the legal consequences of the invalidity of the equity holding agreement in the equity holding, the difference between evading and not circumventing the law, and the inheritance of equity in the holding of equity.

\subsection{Unsound Protection of the Rights and Interests of Related Entities}

Cases related to proxy holding of equity are different from other cases, because most of the cases involve simple stakeholders, and the stakeholders involved in proxy holding include not only companies, nominal shareholders, actual investors, but also creditors of nominal shareholders. On the one hand, the company's shareholders are nominal shareholders rather than actual investors. The actual investors do not directly enjoy the company's relevant rights and interests. Therefore, in the operation of the company, the nominal shareholders exercise their rights, and even abuse their rights to do harm to the actual investors. Coincidentally, the actual investor often uses the shareholder's rights to transfer the equity to a third party as a nominal shareholder, making the actual investor's equity income and the future loss of shareholder rights from "hidden" to "obvious" as a lawsuit. Nominee shareholders go to court. On the other hand, nominee shareholders, as true shareholders of the company, are likely to be claimed by creditors based on the fact that the actual investor's capital contribution is false. Normally, nominee shareholders often have no solvency, which makes it difficult for creditors to claim claims. The real capital contribution is not true, not only make the nominal shareholders, creditors' rights and interests damaged, once the nominal shareholders can not pay, but also lead to the company's operating capital shortage, affect its subsequent operational development.

\section{ANALYSIS ON THE PROTECTION PATH OF CHINESE EQUITY HOLDING}

\subsection{Clarifying the Legal Nature of Equity Holding}

As a member of the company, the original right of shareholders is equity, and at the same time, extendable rights also include self-interest and common-interest rights. The exercise of rights by shareholders is an external expression of their own inner and independent meaning, and the prototype of the exercise of shareholder rights is its independence. The shareholder status of the nominal shareholder in the equity holding means that it has complete shareholder rights attributes, independent expression of intent, and free exercise of rights. Independence of rights does not mean abuse of rights. Once the rights of nominal shareholders are released from legal constraints circle, then it means that the interests of others are likely to be infringed. Therefore, it is inevitable to impose legal rather than intended constraints on nominal shareholders. In the issue of equity holdings, the actual investor entrusts its own equity to the nominal shareholder so that it can manage the equity. The ultimate goal is to obtain equity income. The ultimate goal of the actual investor in the equity holding is for investment and return, not for the management and operation of the company. The selection of nominal shareholders is more favored by people with relevant professional knowledge. From the above characteristics, it is not difficult to see that the nature of equity holding is generally the same as the legal nature of trust, which means that equity holding is a kind of equity trust.

\subsection{Improving Legal Requirements for Equity Holding}

After clarifying the legal nature of equity holdings as a trust, the signing of equity holdings agreement, equity acquisition, equity disposal, and equity inheritance should be included in the perfect scope. The first is that the nominee shareholder and the actual investor sign the equity holding agreement, which is essentially a legal relationship of trust, 
which should fulfill the rights and obligations of the trustee and the trustee in the Trust Law. However, the rights and obligations related to the nominal shareholder and the actual investor can be agreed in the equity holding agreement. Of course, the agreed content must not run counter to the laws and regulations. Read the documents filed by the British shareholder rights company. The most worthy of reference is the equity holding contract. It is filed in the company, but the company should keep it confidential. In this way, the rights of nominal shareholders can be supervised, and it can also reduce the degree of damage to the rights and interests of name shareholders and creditors when the actual capital contribution is not real-time. The second is to clarify that the actual investor enjoys equity rights. The clear basis is that the equity holding is based on the nature of equity trust. Nominee shareholders manage trust finances based on the entrustment of the actual investor, but this entrustment is not permanent, but temporary, that is, the trustee temporarily obtains equity and follows the obligation of proper operation and management. The trustee's disposal of equity is not absolutely independent, but relatively independent, and its relative independence is shown in that it must not violate the purpose of the trust and must not violate its duties to manage the equity and then infringe the rights of the actual investor. Therefore, the author proposes to improve the relevant laws and regulations. When a nominal shareholder abuses his rights and the actual investor's rights are violated, he can apply to the civil court to revoke his sanctions. When the nominal shareholder abuses his rights and damages the rights of others, enjoy the right to claim compensation. The third is the legal provisions of Jingjin's equity inheritance. When the nominal shareholder dies, it means that the trustee's responsibility is terminated in the trust legal system, so the rights and obligations of the trustee can be inherited by the new trustee. If the actual investor dies, the author suggests that the law can regulate whether the heir of the actual investor will disclose the shareholding relationship. If the heir agrees to disclose and more than half of the company's other shareholders agree, the heir of the actual investor will surface and change to Company shareholders; of course, they do not agree to the disclosure. The heirs of the actual investors can appoint a new equity manager, or the original trustee can continue to manage equity trust affairs.

\subsection{Balancing the Interests of All Parties}

The particularity of equity holding is that there are multiple stakeholders. Therefore, rights holders abuse their rights to infringe others' rights and interests one after another, and it is inevitable to balance the rights and interests of all parties. The first is to give the actual investors the power of supervision. Nominee shareholders are the actual shareholders of the company, so it is easy to abuse shareholder rights. However, actual investors often find out afterwards that they cannot be stopped in time. Granting their supervisory powers can prevent nominal shareholders from abusing their rights to a certain extent. The second is to give creditors the right to claim compensation. When the creditor damages its rights based on the abuse of rights by the nominal shareholder, the company can prove that it has not reached an agreement with the nominal shareholder for the abuse of rights, and the creditor can directly claim compensation from the nominal shareholder. The third is to give the company the right to claim compensation from the actual investor. The actual investor often hides behind the scenes and uses the feature of hiding his identity to circumvent the obligation to contribute capital to the company, resulting in insufficient operating capital of the company and harming its interests. Therefore, when the capital contribution of the nominal shareholder is false, the company may require the nominal shareholder to disclose the relationship of holding shares with the actual investor and directly seek compensation from the actual investor.

\section{CONCLUSION}

On the one hand, equity holdings can meet the needs of investors and broaden investment channels; at the same time, it can also increase the company's operating capital and ease the company's financial pressure. With the gradual development of Chinese market economy, equity holdings will generally exist in companies. From the basis of legal theory and economics, the existence of equity holdings is justified and reasonable; from a realistic perspective, equity holdings also have its inevitability. Therefore, only relying on the existing laws of the equity holdings is not enough to resolve many disputes caused by the equity holdings in China. In view of this, this article puts forward tentative suggestions on equity holdings, hoping to make some contributions to market transaction security and market investment order.

\section{AUTHORS' CONTRIBUTIONS}

Hanyu Tang is responsible for writing, and Debin Hou is responsible for modification. 


\section{REFERENCES}

[1] Xiaoli Wang, Several legal issues of equity holdings from the perspective of corporate governance [J]. 3rd ed., vol. 2. China: Arbitration Research, 2015, pp.10-15.

[2] Jiayong Xu. Listed companies' equity holdings and the handling of disputes [J]. 3rd ed.,vol. 3. China: Journal of China University of Political Science and Law, 2019,pp. 105-124.

[3] Xiaojing Hu, Zhiwei Cui. Research on Legal Issues of Limited Liability Company's Stealthy Capital Contribution Interpretation of Company Law Interpretation [J]. 3rd ed.,vol. 4. China: Contemporary Law, 2012, pp.34-40.

[4] Junhai Liu. Modern Company Law [M]. Beijing, CNKI: Law Press, 2015.

[5] Baoyu He. Principles of Trust Law [M]. Beijing, CNKI: China University of Political Science and Law Press, 2005.

[6] Guixiang Liu. Research on Contract Validity [M]. CNKI: Beijing.People's Court Press, 2012.

[7] Xudong Zhao. Corporate Law [M]. CNKI: Beijing Higher Education Press, 2006.

[8] Tiantao Shi. Corporate Law [M]. CNKI: Beijing Law Press, 2010. 